\title{
Imagining Indian Literature: Towards a Historiography of Translation
}

\section{Mringoy Pramanick}

Research question what this paper tries to address is the role of translation in imagining nation and national literature in Indian context from a bhasha perspective. This paper argues that a partial history of literary translation can be proposed from the act of imagining national literature in a certain language. Research in this subject concerns on the history of literary translation by the government and non-government publishing houses, academic disciplines and academic activities like seminar, conferences, symposium, workshops etc. as the stepping stones for imagining nation through translation. This paper took quite a few examples of above mentioned literary activities to propose a history of translation as well as the history of Indian literature in a bhasha context.

Keywords: Indian literature, nation, national literature, historiography, bangla translation, ecology of translation.

... the major modern Indian languages have developed not only through 'vertical' translations from the languages of power and knowledge - English and Sanskrit - but also by engaging in 'horizontal' translations of one another, ultimately contributing to the creation of an inherently pluralistic body of literature in India. (Translation as Growth: Towards a Theory of Language Development, Uday Narayan Singh).

Imagining Indian Literature in Bangla can be traced back from $19^{\text {th }}$ century with the translation of Indian literary texts from West Indian languages by Jyotindranath Tagore and also with the translation of Rabindranath Tagore's translations of Indian poetry. This paper traced the history of translation and imagination of National literature from early $20^{\text {th }}$ century as theoretically Indian Literature were assumed to be studied. Sir Asutosh Mookerjee's lecture on "Jatiya Sahitya" in 1913 and consecutively establishment of the Modern Indian Languages department in the University of Calcutta initiated conscious effort to study Indian Literature in an academic discipline and translation was major tool of study. I consider this initiative as the systematic beginning of practice of Indian Literature in India as well as Bengal. This paper discusses the publications and other initiatives regarding translation and the role of different publishing houses including Sahitya Akademi, National Book Trust, National Translation Mission, and various State Akademies for the promotion of literature which are supported by central government and 
other state initiatives. This paper mainly takes up for discussion the initiatives of private publishing houses and those houses which are limited into Bengal. Therefore the effort of Sahitya Akademi and National Book Trust purposefully kept aside as these institutions have altogether different politics in literary business.

The combined impact and effort of the academic institutions, academic activities like seminar, workshops and publishing translated literatures made the category of Indian literature. Such efforts also sensitize national awareness and spread national literatures. In my view the process of nation building is well served through the dissemination of literature through the creation of such literary spaces and the encouragement with translation. India is a multiligual country and networking among many languages and literatures is both imperative and essential for nation building. But not only translation and their publication or circulation, proactive and determined promotion of Indian Literatures, Translation Studies and Comparative Literature must be emphasized for enhancing and enlarging the idea of nation and national literatures. Within the nomenclature of national literatures is also included their translation. This paper has two sections, one on translation and the publication houses; the other is on academic disciplines and the role of other institutions.

As Bachelor of Arts in Bangla language and literature, a graduate in Comparative Indian Language and Literature and a research scholar of Comparative Literature doing research in a State [other than my own] where the medium of instruction is English (whereas the earlier degrees are in mother tongue medium), I am confused about the 'territory of national literature' and the idea of identifying myself with 'national literatures'. In the country like India where English has been accepted as an official language, rather as the most dominating official language even in regional sectors also, I grapple with English hegemony. I must admit that English is 'foreign' to my literary imagination as I am not competent enough to use it. It is not a typical Indian mother tongue though these days many urbans choose English for communication. Indian writing in English and Translation Practice in India are popular now but, I feel that to truly 'imagine the nation' one may need bhasha or one's mother-tongue. So, placing 'Indian' before 'English' problematizes the notion of national literature and national identity. It gets equated with a mono-lingual culture. This "mono-lingual cacophony" (G. N. Devy's term) disturbs me and my imaginition of national literature and identity. But the situation must be much more difficult for those whose mother-tongues are marginalized and there are very few literary texts available in their languages either written or translated. As a Bengali I am privileged in that sense as there is a long and rich heritage and culture of imagined/constructed nationhood we have been grown up with. But what about Bhanumati (protagonist in Aranyak/Bibhutibhushan Bandopadhyay, a novel on tribals) who asks Satyacharan: "where is this India?" Spivak's theory of nation may be contextualized here, as she rightly points out that "the 218 
'nation' is a hegemonic or oppressive structure willfully imposed on the "subalterns" (Paranjape: 114). In Aranyak, Satyacharan, a Bengali bhadrolok brings the information of nation to Bhanumati. Nation is imposed to Bhanumati who has no idea about it nor can imagine it. So, those who are more privileged have a greater sense of 'nation'. So, nation building depends on the practice of basic rights of people about to stay and live in a particular space. When I talk about translation and nation building, it takes into consideration those cultures and people who can access the state. Here, the Indian nation does not mean the total geographical territory of India and does not cover all the linguistic and cultural communities of India, many of whom still remain excluded from the whole project of 'nation-building'.

It is desirable that translation is seen as a collaborative work through which every medium can get represented. Translation is collaborative work and its influence also results of this collaboration. The source text author (text to be translated), target text author, publishing and circulation (it is common for any other book publishing also), critic or reviewer, readers, practitioners in an academic discipline - everybody helps to create the public life or bring translation into the public sphere. Thus the process of nation building also happened through these mediums and they promote the afterlife of the translated text. Paul St. Pierre pointed out the same with more elaborative discussion. Bijay Kumar Das discusses the role of translation in nation building and takes a nationalist approach promoting the 'Unity in Diversity' principle and believes that no other way is possible for integration. But the question of 'nation building' has always encountered the question of believability. The post- 1990s incidents make this more challenging and complex.

Most of the modern Indian languages and literatures have benefitted through their interaction with literatures of Europe via translation. But there are always exceptions, as for example, Dogri language and literature developed with the resurrection of oral and folk traditions and culture after the availability of print technology. Indian bhasha literatures share a common ground of history, social movements, political movements and tradition of literary genres and themes. Here is the root of integration among different bhasha literatures. Amiya Dev's 'plus' theory of individual Indian literatures talks the way every literature evolved and grew in affiliation with other Indian languages and literatures. Dev comments,

...the method of Comparative Literature allows for a view of Indian literature in the context of unity and diversity in a dialectical interliterary process and situation. There was a time when I spoke in terms of an extra consciousness on the part of individual langua-ge writers: for Bengali literature, for instance, I saw a Bengali+, for Hindi literature a Hindi+, for Tamil literature a Tamil+, etc. My understanding of Indian literature consisted of the author's extra consciousness and not of an archivable entity as such but rather a 
state of mind in order to justify the unity of Indian literature. However, today, with a focus on reception and the theoretical premises offered by the notion of the interliterary process, I understand Indian literature as ever in the making (Dev: 6).

This connection among Indian literatures hints towards the literary relationships which are built through migrations of language, themes and concepts, and translation, though the role of non-literary mediums or elements such as, academic disciplines, literary festivals so on cannot be ignored. Amiya Dev mentions certain periods when history of literary-plus tradition was made. Meenakshi Mukherjee, while explaining the mutual translation among Indian literature in the context of novels, writes that in the recent past the trend of mutual translation has declined and now the trend is progressively from one Indian language into English (109). Both critics talk about a particular past when Indian literatures were growing with each other.

Languages, literatures and cultures which have been represented through different mediums (literature, film, advertising, newspapers etc.) have their own kind of 'nationalism' and cultural identity. Modernism in those Indian literatures came with print technology and the translation of English texts (in many senses). So, the whole notion of literature which has been popularly taken for granted is basically colonial as were some of the genres too. The translation into one another's language brings alive that colonial memory, history and ideologies of those genres of colonial modernity. I would like to call it 'generic imperialism' which is found as a common denominator of Indian literature to be identified as one. Those who believe in the saying that 'Indian literature is one though written in many languages' also believe in 'unity in diversity' and claim that different parts of India share almost same historical past. But this idea excludes many people and many literatures which exist far from this colonial modernity, like tribal and folk literature. One must contend with the fact of there being other literatures which do not belong to generic imperialism and do not share this common denominator of Indian literature which identify with only the centre of Indian literary system. Behind the apparent oneness (which is constructed) of Indian literature, there are many and different Indian literatures. Hence the importance and mobility among the literatures of different cultures, races and linguistic geography should be there to imagine the nation through literatures.

\section{Translating Premchand, Translating Metaphor: Imagining Indian Literature}

Pashchimbanga Bangla Academy publishes translations, like the voluminous collection of Premchand's short stories, first published in 1988, then reprinted in 2001 and 2006 (I have information only till 2006). In his note, the then secretary of Pashchimbanga Bangla Academy Sanat Kumar Chattopadhyay writes that Bengali readers have great affinity with Premchand so the volume is published in the eve of his birth centenary. This anthology carries a long 
introduction by eminent scholar Pabitra Sarkar who compares Premchand's style and philosophy with that of Dickens and Gorky. Sarkar also discusses the methods for translation. ${ }^{1}$

Hence, the process of this anthology-making as elaborated above is possibly one of the best examples of translation method. Whole entire project illustrates care taken at every level to convey an 'authentic' Premchand to non-Hindi/Urdu readers. Premchand is observed here as one of the symbols of Indian Literature. Translating Premchand is assumed as making Indian Literature.

\section{Translating Indian Literature: The Role of Private Publishing Houses}

Many private publishing houses have helped to promote translation of Indian literatures in Bangla. It will be useful to remember that there are different forces at work behind translating Indian literature. During 1940s, many small publication houses in Kolkata printed progressive literature influenced by the Indian Progressive Writers' Association. For example, Radical Books Club published translation of Mulk Raj Ananda's Daraj Dil by Swati Sen in 1946. This book cross-refers to other translations by the same publisher. Bangla titles of some of these books are: Kuli, Duti Pata Ekti Kuri, Achchut, Narasundar Samiti, Private Life of an Indian King and so on. Premchandra appears as one of the most significant symbols of Indian literature as well for translation. Premchand's Dui Sakhi was translated by Subimal Basak and published by Tin Sangi publishers in April 1985. Juba Prakashani published Premchanda Rachanabali in 1991 by various translators like Shila Choudhury, Dhananjay Bandopadhyay and Subrata Sarkar. This is now a rare book as copies have disappeared and the publication house has ceased to exist. Different decades find different symbols while imagining National or World Literature. Sadat Hasan Manto is another popular symbol. Though his most of the writings were written in Pakistan, he is celebrated for Partition stories. His birth centenary was celebrated in different places of Bengal and

\footnotetext{
${ }^{1}$ The method of translating and editing of this collection was like this: editors selected 80 stories from the first to last phase of Premchand's creative oeuvre. Some of the best stories are selected as well representative story from each phase of his writing career. The aim was to trace the growth and variety of his writing style and his immense and diverse experience of life. After that stories were given to the translators. Knowledge of TL was not enough, the translators had to compare different versions of the same story. It was observed that Man-Sarovar, the collection of all most of his stories is quite different from many smaller collections. Also, there are differences between Urdu-Hindi readings of the stories at least that happened in the first phase of his life. Editors discussed with Premchand's son Amrita Roy and took Man-Sarovar as most authentic collection

When translations were submitted, experts from Urdu, Hindi and Bangla language examined them through several meetings. The concern was about retaining the linguistic style of the original text in Bangla. How far they are successful, will be evaluated by the readers. Editors are happy and grateful they have gifted this collection to the readers. So many stories in one collection is not available anywhere in Bangla. In second edition we have added three more stories (translation mine).
} 
invariably many translations of his writings were published. He is mainly popular in Bengal because of his Marxist ideology and continuous protest against the British and orthodox society. National Book Agency, which publishes radical literature published translations of Manto's of short stories by Sanchari Sen titled, Sadat Hasan Mantor Galpo. Many little magazines published Manto birth centenary issue. Nabarun Bhattacharya translated Manto's story Thanda Gost O Anyanya Galpo from Bhashabandhan publisher in 2013. Arup Kumar Das, professor of Bengali of the University of Calcutta published translation of Manto's story from the Rabindra Bharati University press. Sharmila Bagchi translated Sadat Hasan Mantor Nirbachito Galpo in 2010; this translation was published from Ekush Shatak. All these translations carry introductions on Manto and/or translator's notes. Bagchi writes in her note,

"As far as I know, there are very few translations of Manto in Bangla. But I feel Manto is very significant for the struggle of human beings in modern society" (Bagchi) (translation mine).

Translator Bagchi wrote a long introduction on Manto and his short stories. This introduction is useful to understand the relations of different Indian Literatures. She presents her points in a comparative framework, comparing Manto with other Urdu and Panjabi writers; while talking about Partition, she compared with Prafulla Ray; and while talking about the genre of Anugalpo (Very Short Story), she compares him with Bengali writer Bonoful. Manto's Ganje Fereshte is an important account on the history of Hindi cinema, and was very popular. This book is translated by Mostafa Harun with introduction by Sandipan Chattopadhyay and summarized by Chandi Mukhopadhyay, published by Prativas in 2009. Sandipan Chattopadhyay's introduction explains that the book was also translated earlier and he found that translation in the private library of Partha Choudhury. But no details about this translation are given. The introduction adds another information that this book was serially translated since June 1967 in a film magazine called Chitrali published from Dhaka, Bangladesh. Harun's translation was reprinted 1985 and 1989 before it was published by Prativas. It shows the enormous popularity of the book. .

Another translation anthology published by Mitra and Ghosh publisher of Kolkata is Bharatjoda Kathankatha (2012), edited and collected by former secretary of Sahitya Akademi, Ramkumar Mukhopadhyay, who is himself a translator and a creative writer. He had a clear political motivation for this collection. He writes in his note that Sarvapalli Rahdakrishnan's comment ${ }^{2}$ on Indian Literature is not unbiased as it talks about the written culture but there are thousands of literary productions and cultures in India which are neither written nor collected. So, one does not have any idea of these Kathas which are scattered all over of the country. Some of these literary cultures were

\footnotetext{
2 "Indian Literature is one though written in many languages".
} 
discovered by the colonizers and seen from the colonizer's point-of-view, sometimes from the imperial religious view or as exotic. But the reality of their life lies beyond all these perspectives. So, this collection has been prepared and could successfully contradict with the views of the colonizers and the imperialists, and tries to represent the plurality in Indianness and the country's the Bhasha culture. This collection was has stories by Lakshminath Bezbarua, Dakshinaranjan Mitramajumdar, Javerchand Meghani, Madhuram Malu, Bhagabandas Patel, Debabrata Joshi, Taranimohan Rupini. The title of Ramkumar Mukhopadhyay's introductory note on "Swadesher Katha O Kahini" is significant here. He wants to imagine Desh and Swadesh in the postmodern era. According to Bauman, "Johann Gotfried von Herder, in whose vision the oral literature of a people was both the highest and truest expression of its authentic national culture and the appropriate foundation of its national literature". Similar is the vision behind the project of translation of folk narratives. This collection claims Swadesh, and it claims it is possible to find the essence of the Swadesh even in the time of imposed culture of globalization. The collection has 108 stories from 52 languages. Ramkumar Mukhopadhyay says that this kind of Katha which existed in oral cultures among the common folk who had no literacy or education to construct the alternative history of India. This collection is in search of that alternative history. He found the 'self' deeply rooted in the memory of past, which lives in all narrative of traditions of India, and must be the same in other ancient cultures too. He writes,

There are diverse ways to live and let live. We can find parallel history from these like William Carey's Itihasmala. And Haricharan Bandopadhyay informed us that one of the meanings of the word 'Itihas' is something which is there in the tradition. So, in this parallel history, self and memory are deeply rooted. In search of that Indian history I have collected 128 stories from 52 languages (Mukhopadhyay, Ramkumar) (translation mine).

Earlier to this collection, Ramkumar Mukhopadhyay published another collection titled Bharotjora Galpakatha, (2007-2008) from the same publication house. The Introduction of the editor, "Bharatbarsher Sandhane' is interesting. It seems Ramkumar Mukhopadhyay began to conceptualize 'Swadesh', digging into the memory of traditional Indian narratives. There were different initiatives to write the history of India through different expressions of the people. Vatious kinds of literature reveal different thoughts on the Indian nation. He writes,

Literature of one language is sent to the readers of another language through translation. From this process we have received not only the expansion of aesthetic but we started to know this country differently. ... Still, from these 45 stories of 18 languages 
will show us Indian life of last 100 years (Mukhopadhyay, Ramkumar) (translation mine).

Ramkumar Mukhopadhyay is an eminent scholar of Indian Literature and served as the secretary of Sahitya Akademi in the eastern region. He understood the need for to know Indian literature through Bangla language. These two collections of translation present a rich resource for the Bengali readers. In the second collection he briefly discusses the traditional narrative as he did in the first one. These two books expand literary value and aesthetics and can be treated as source books of Indian literature for Bengali readers. A similar initiative was also taken by National Book Trust when they published a book on Indian folk tales collected and edited by A. K. Ramanujan and its Bangla translation by Mahasweta Devi as Bharater Lokakatha (1998). Even earlier to these, Gujarati Lokakatha was published by Best Books, a private publishing house from Kolkata in 1992. This book is by Ratul Bandopadhyay, who was a student of Bengali literature and a journalist who felt that Indian culture can be known best through folk tales, the voice of the people. The same publisher also printed folk tales of Bihar, Assam, Andaman Nichobar, Punjab and the folk tales of Santhali community.

Among Indian Literatures, Urdu has a popular literary tradition. There are many books on the development of Urdu language and literature, for example Touhid Hossain's Urdu Kabyer Bhuban published from Karuna Prakashani. On one side there is a long tradition of Urdu and Hindi writing of Premchand; on another side, a separate tradition was built with Manto and Ghalib. Sahitya Akademi has published a large collection of Ghalib's ghazals along with Ghalib's biography. Ghalib is not only a Urdu poet but another prominent symbol of Indian Literature. There are several translations of Ghalib, published from different publication houses.

Since a long time Ghalib was being translated into Bangla by various agencies, governmental or private. In this context it must be remembered that theatre plays important role in creating awareness and space for Indian Literature. There are many examples of such texts or authors who are not translated into Bangla language but performed on Bengali stages. This cultural expression also contributes a lot to form the idea of Indian Literature. Famous Bengali poet Kazi Nazrul Islam was very influenced by Ghalib and wrote ghazal-style poetry in Bangla. Though ghazal as a literary genre is not used in Bangla but Ghalib's popularity transcended that. It cannot be that Ghalib's popularity was due to the transition in Bengali theatre or Bangla translation of his poetry, but definitely because of Ghalib's universal talent which cannot be limited into a particular language, culture, religion or literary space. But the point is, Ghalib is equally appreciated by the Bengali authors, critics and readers. A good translation of Ghalib was done by critic Abu Sayed Ayub, an Urdu speaker. His translation of Ghalib's shayeri was first published serially in a leading Bengali literary journal Desh, then published in 1976 and reprinted in 2010 by Dey's Publishing House, one of the most 
dominating publishing housees of Bengali literature, culture and history. Ayub is an eminent scholar of Urdu and Bangla literature. His descriptive note on Ghalib and his own method of translation which he calls literary but not a mechanical word to word translation since the symphony of Urdu into Bangla requires certain amount of freedom. Ayub translated Ghalib in prose form and discusses the problems faced while translating. The book can be considered a source book Ghalib and ghazal and a perfect example of comparative study of literature as Ghalib is compared with different Urdu poets, even Tagore. Thus Ayub presented Ghalib to Bengali readers with all the possible dimensions to understand Ghalib.

More than the 'symbols of Indian Literature', I would like to discuss the role of few publishing houses especially Prativas, Bhashabandhan etc. which are leading publishers of translations offering different Indian and World Literatures. I wish to draw attention to the politics of selection of texts for translation. Bhashabandhan is an important publisher and also publishes a. Monthly journal on Indian and World Literature besides translated books and creative writing. A brief list of its publication is given as Appendix 1, though not the list of translations from the monthly journal because the number would be enormous. In addition to the translation of Modern Indian Literatures, there is long history of translating ancient Indian texts and religious texts. Nowadays, the ancient Indian texts are received in two distinct categories, firstly as religious texts for Hindus, Muslims, Buddhists; and secondly as literature, like the Ramayana, the Mahabharata, the Jataka, the Padmabati etc. Religious texts of other religions are popular as literature among some readers and scholars. Gorakhpur Geeta Press and Udbodhan Karjyalay of Ramakrishna Mission are pioneering institutions for publishing such translations besides private commercial publishing houses like D. M. Library, Karuna Prakashani, Deb Sahitya Kutir, Akshay Library etc. This paper does not focus on texts which are primarily received as religious texts by the greater audience.

\section{Adivasi Literature, Translation, and Conceptualizing Indian Literature}

Adivasi literature, especially of the Santhali communities which live in close contact, is of much concern to the Bengali literate society. Santhali rebels like Birsa Munda, Sidho, and Kanho are nationalists [though not acknowledged earlier histories] for opposing British imperial forces. Comparatively much attention had given to the Santhalis and whatever attention is given has also been self-serving for the Bengalis. The limited knowledge about Indian tribal shows negligence and ignorance about their rich traditions and culture, though this is being rectified. Pashchimbanga Bangla Academy has published Bengali-Santhali dictionary about a decade ago. Jadumani Besra and Subodh Hansda, two well-known translators from Bengali to Santhali and vice versa try to make communication easier between two communities. This initiative of Bengali-Santhali translation project is not only about imagining Indian Literature but it is about to understand the cultural geographic reality of 
Bengal. Certificate and degree courses in Santhali in different universities of West Bengal are a welcome move. Subodh Hansda's translation of Santhali story has been included in the Bengali literature syllabus of University of Calcutta. Best Book's publication of Santhali Lokakatha is a noteworthy initiative to enrich knowledge about their culture. Tapan Bandopadhyay and Animesh Kanti Pal are well-known translators of Santhali literature into Bangla. The edited Saotali Kabita has more than two hundred poems and songs of the Santhals. This book was first published in March 1976 then Deys' edition came in November 1980, reprinted in January 2010, endorsing the popularity of the volume. Recounting the history of translation of Santhali is important to prove the interest of the people in the rich Santhali culture and literature and to encourage more texts and documents on the subject to provide material for study in schools and universities. The initiative for translating Santhali literature is supports the desire to know the neighbour, not just as an exotic remainder from the past (Mahasweta Devi's remarkable story about Pterodactyl comes to mind). Yet, for the translator of Santhali literature must also grapple for space in the literary culture of the language to be heard.

In 1955, a Bengali Daily Dainik Basumati carried an item on Sri Gurudas Sarkar's Saotaldi Katha published by Biswabani. The perception reflects in the report on translation of Santhali stories into Bangla shows that contemporary Bengali society was unaware about the community and their literature, culture and existential problems. The book was an initiative taken to know the 'Other' who is actually a neighbor. The book's intended readership was the children and the translator hoped these stories of the marginal community will find place in the world of Bangla children's literature which already had accommodated from the world. This review of the book mentions $18 / 19$ pictures made with woodcut painting to accompany 9 stories.

But not only Santali, Lepcha or Kokborok, Monfokira, a private publishing house publishes Missing ${ }^{3}$ poems of Assam, So on Shiri Ar Jonbeli, translated by Manik Das. March- April 2008 issue of a literary magazine, Kabita Pratimaase published a review of this collection by Krishanu Basu, who clearly wrote that this initiative is for becoming Indian, to imagine and know India and diverse literary culture of India.

Translations from other languages into Santhali is rare but can expand their world view, and is being introduced in some schools and colleges. But the tribal languages have to fight to survive, more in these times. A teacher of Translation Studies, Professor Shivaram Padikkal says if there was no translation such languages would become stagnant and thereafter die. Padikkal maintains that a translation is like a window to the world. If a language does not accept translated works it may suffer from poverty of knowledge (News Correspondence). The translation of Santhali literature or any other tribal literature in a dominating language or a language of power in

\footnotetext{
${ }^{3}$ A tribal community from Assam and Meghalaya. 
a specific geo-cultural area is a way of building knowledge or to know the small voices of history.

\section{Dalit Literature and Translation}

History of Dalit movement and Dalit literature in Bengal is about 100 years old. The Dalit movement of Bengal is mainly driven by the Namasudra community of Bengal. The Partition of Bengal divided this community which spread to several neighboring States like Tripura and Assam. Namasudra Dalits are a majority community in Bengal now, having come at the time of the Partition. In a long essay on Bengali Dalits, I have tried to establish that West Bengal Dalit movement is not consolidated because of the uprootedness caused by the Partition. Since the last two decades, Dalit mouthpiece Chatortha Duniya is trying collate the history and literature of this community in relation with the Dalits of other parts of India. Chaturtha Duniya (Fourth World) regularly publishes translations of Dalit literatures from different parts of India. It encourages discussions on Dalit literature, society and politics. Its August 2001 issue was dedicated to Phoolan Devi. Another Dalit magazine called Neer (Nest/Home) edited by Kalyani Thakur Charal also publishes Bangla translations of Tamil, Marathi, Telugu, Hindi Dalit writing. The June 2011 issue of Neer published translation of Tamil Dalit poetry, and poetry in a marginalized language which is called Chnai Bhasha. The December 2011 issue published translations of Tamil Dalit short stories and the June 2012 published Dalit women writing from Tamil, Telugu, Kannada, Marathi and Gujarati. Besides this, different publishing houses have also started to publish translations of Dalit literatures. A noteworthy volume is edited by Debesh Roy called Dalit published by Sahitya Akademi. National Book Trust also published two collections of Dalit writings titled Kissa Gulam by Rameshchandra Saha, Daas Kahini by Ajit Ray.Ekush Shatak. A publication house from Kolkata, which focuses on people's movement and literature, published Dalit $O$ Rabindranath by Chitta Mandal. Debu Dattagupta translated Dalit Bharat, originally written by P. Sainath published from Seriban in 2011.

Swapna Banerjee-Guha, a Mumbai based professor and translator, translated a collection of Marathi Dalit poems, Chhander Alinde Bidroho (2012), by Thema publishers, Kolkata. This collection traces the whole history of Marathi Dalit poems and selects representative poems of the poets. This translator has her personal contact with the poets and poets also have seen this collection translated into Bangla. Translator here included a long introduction on Marathi Dalit literature and there is very brief introduction of poets in the concerned sections where their poems are translated. In an interview with me she told she has to write a long introduction and note on poets as most of the Bengali readers do not know much about Dalit literature and she believes this collection also will contribute to find the Dalit history in India and consolidate Dalit movement and identity in Bengal (BanerjeeGuha). 


\section{Conclusion}

This paper tries to show that the history of translation has its own ecology. It develops with the interconnections among the academics, government initiatives, private initiatives, theoretical writing, public discussions, publishing and readership, a total consciousness. Process of nation building through translation is still an emerging practice.

Shankha Ghosh's work Oitihyer Bistar has been paid much attention in this ecology of translation. Manabendra Bandopadhyay, reputed translator in Bangla and former professor of Comparative Literature at the Jadavpur University translated five volumes of collections of Indian short stories into Bangla being influenced by the essay written by Shankha Ghosh.

This paper is assumed as an introduction to propose a historiography of national literature/ Indian literature which is made through translation in a bhasha. In other words, it is a historiography of translation into bhasha also. There are many other initiatives which are to be addressed to understand the complete ecology of literary translation in a bhasha context have been mentioned in the introduction of the paper.

\section{References}

BAGCHI, SHARMILA. (trans.) 2010. Sadat Hasan Mantor Nirbachita Galpo. Kolkata: Ekush Shatak.

BANERJEE-GuHA, SWAPNA. 2014. On Translation of Marathi Dalit Literature into Bangla Mrinmoy Pramanick. Recording.

BASSNETT, SUSAN. 2002. Translation Studies. New York: Routledge.

BASU, KRISHANU. 2008. Book Review. Nadi Parer Batas Jhirjhir kore Boy. Kolkata: Prativas.

BAUMAN, RICHARD. 1986. Cambridge Studies in Oral and Literature Culture/ Story, Performance and event/ Contextual Studies of Oral narratives . Cambridge: Cambridge University Press.

DAS, BIJAYKUMAR. 2005. A Handbook of Translation Studies. Delhi: Atlantic Publishers and Distributers (P) Ltd.

Das, Saswata; Purkayastha, AnindyasheKhar;. "From Pedagogical to Performatives: Re-Postcolonizing Indian Sahitya Akademi." Unpublished, n.d.

Dev, AMiYA. 2006. Comparative Literature and Culture. 2.4: 6. Online: $<$ http://docs.lib.purdue.edu/cgi/viewcontent.cgi?article $=1093 \&$ context $=$ clc web>.

DHIBAR, DEBDIP. 2011.Bangla Anubad Parikalpana: Saotali Bhasha Sahitya. Unpublished M.Phil. Paper. Kolkata: Comparative Literature, Jadavpur University, August 2011. Print.

"Ganakristi: A Beacon for the Group Theater Movement in Kolkata." 4 October 2007. <http://nynjbengali.com/ganakrishti-a-beacon-for-the-group 
-theater-movement-in-kolkata/>.

GHOSH, SHANKHO. 2006. Oitihyer Bistar. Kolkata: Papyrus.

HARUN. 2009. Ganje Feresta. Kolkata: Prativas.

KRIPALANI, KRISHNA. 1978. Making of One Indian Literature. In Arabinda

Poddar (ed.), Comparative Indian Literature. 16-22. Shimla: Indian Institute of Advance Study.

MuKherJeE, MeEnAKSHI. 2005. Divided by a Common Language: The Novel in India, in English and English Translation. In Kamala Ganesh and Usha Thakkar (eds.), Culture and the Making of Identity in Contemporary India. 108-124. New Delhi: Sage.

MUKHOPADHYAY, RAMKUMAR. 2007-08. Bharatjora Galpokatha. Kolkata: Mitra O Ghosh.

MUKHOPADHYAY, RAMKUMAR. 2012. Bharatjora Kathankatha. Kolkata: Mitra O Ghosh.

National Book Trust. n.d. 2 February 2015. <http://www.nbtindia.gov.in/ aboutus_5_ history.nbt>.

News Correspondence. 2015. Seminar on Knowledge Text Translation in Kannada. Mangalore, 29th Jan. News Paper. Online: <- http://www.them angaloretimes.com/news/seminar-on-knowledge-text-translation-inkannada-begins>.

PARANJAPE, MAKARAND. Nativism Essays in Criticism. In Makarand Paranjape(ed.). Delhi: Sahitya Akademi, 1997. 114. Print.

PRAMANICK, MRINMOY. 2013. Banglay Bharotiya Sahitya Charcha: Oitihasik theke Samprotik. Charbak. 54-64.

PyM, ANTHONY. 2010. Exploring Translation Theories. New York and London: Routledge.

Sahitya Akademi. n.d. 31 January 2015. <http://sahitya-akademi.gov.in/ sahitya-akademi/index.jsp>.

Sampadokiya. 1955. Dainik Basumati. Saotaldi Katha. Kolkata: Basumati Private Limited, 2 January.

SARKAR, PABITRA. (ed.) 2006. Premchanda: Nirbachita Galpo Sangroho. Kolkata: Pashchimbanga Bangla Academy.

SEN, SANCHARI. (trans.) 2013. Sadat Hasan Mantor Galpoguchcho. Kolkata: National Book Agency.

SteINER, GEORGE. 1998. After Babel. UK: Oxford University Press.

"We've Got a Way Words: The Found in Translation Workshop." n.d. Berlin's English Literary Journal. Web. <http://www.sandjournal.com/ news/weve-got-way-words-found-translation-workshop $>$. 